\title{
CrystEngComm
}

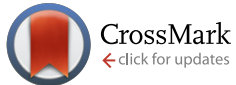

Cite this: CrystEngComm, 2016, 18 , 7675

Received 29th August 2016,

Accepted 26th September 2016

DOI: $10.1039 / c 6 c e 01887 d$

\section{A nacre protein forms mesoscale hydrogels that "hijack" the biomineralization process within a seawater environment $\uparrow$}

\author{
Martin Pendola, $t^{\mathrm{a}}$ Gaurav Jain, $+^{\mathrm{a}}$ Anastasia Davidyants, ${ }^{\mathrm{a}}$ Yu-Chieh Huang, ${ }^{\mathrm{b}}$ \\ Denis Gebauer ${ }^{b}$ and John Spencer Evans*a
}

www.rsc.org/crystengcomm

We examined the mineralization performance of a nacre protein, AP7, within seawater mineralization assays that form aragonite and magnesium calcite. Under these conditions AP7 forms hydrogel particles that vary in size and complexity depending upon ionic conditions. These hydrogels "hijack" the mineralization process by limiting nucleation in bulk solution and promoting nucleation within the hydrogels.

The aragonite polymorph is a primary mineral component of many invertebrate oceanic skeletal elements, such as the mollusk shell nacre layer, ${ }^{1-6}$ and is one of the oldest examples of crystalline metastability in Nature. ${ }^{7-10}$ Typically, the equilibrium form of calcium carbonate, calcite, forms from the assembly of nanometer-sized mineral clusters, known as prenucleation clusters, $(\mathrm{PNCs})^{11-17}$ into an amorphous calcium carbonate (ACC) precursor that subsequently transforms into calcite under ambient conditions. ${ }^{18-21}$ However, stabilizing agents, such as $\mathrm{Mg}$ (II) ions, can promote aragonite formation instead. ${ }^{7}$ This is clearly seen in invertebrate organisms that live in seawater, where the ratio of $\mathrm{Mg}$ (II) to $\mathrm{Ca}(\mathrm{II})$ is approximately $5: 1$ and a $\mathrm{Mg}$ : $\mathrm{Ca}$ ratio $>2$ is known to promote aragonite and magnesium calcite $(\mathrm{MgC})$ nucleation and inhibit calcite nucleation. ${ }^{1,7-10}$ Since the mollusk creates and assembles aragonite within a nacre macromolecular matrix, ${ }^{422-24}$ it is plausible that nacre protein families, or proteomes, manage the ACC - to - aragonite formation process in the presence of $\mathrm{Mg}$ (II).

To learn more about this $\mathrm{Mg}(\mathrm{II})$ - protein-mediated process we adapted an existing microvolume calcite-based rapid in vitro mineralization assay $(0-60 \mathrm{~min})^{25-27}$ to foster aragonite and $\mathrm{MgC}$ formation using seawater ratios [i.e., 5:1

\footnotetext{
${ }^{a}$ Laboratory for Chemical Physics, New York University Center for Skeletal and Craniofacial Medicine, 345 E. 24th Street, NY, 10010 USA. E-mail: jse1@nyu.edu

${ }^{b}$ Department of Chemistry, Physical Chemistry, Universität Konstanz, Universitätstrasse 10, Konstanz D-78457, Germany

$\dagger$ Electronic supplementary information (ESI) available. See DOI: 10.1039/ c6ce01887d

\$ Both authors contributed equally to this work.
}

$\mathrm{Mg}$ (II): $\mathrm{Ca}$ (II)] at $\mathrm{pH} \sim 8.0-8.5 .^{7}$ Note that the actual $\mathrm{Mg}$ (II): $\mathrm{Ca}$ (II) ratio in the mollusk nacre matrix is not known at pres$\mathrm{ent}^{7}$ and thus our selection of the $5: 1 \mathrm{Mg}$ (II): Ca(II) seawater ratio represents an initial starting point for nacre protein aragonite studies. Within this model system we tested the ability of an intrinsically disordered, amyloid-like aggregation-prone abalone shell nacre protein, AP7 (Haliotis rufescens, $\mathrm{MW}=7565 \mathrm{Da}, 66 \mathrm{AA}, \mathrm{pI}=5.85),{ }^{25-28}$ to modulate the formation of aragonite, MgC, PNCs, and ACC. Here, we find that AP7 forms porous hydrogel particles (Fig. 1, top panel) over a range of ionic conditions at $\mathrm{pH}$ 8.0. Flow cytometry measurements demonstrate that $5: 1 \mathrm{Mg}$ (II): $\mathrm{Ca}(\mathrm{II})$ induces the most significant increases in hydrogel particle dimensions (FSC parameter) and alternations in granularity or internal structure (SSC parameter) (Fig. 1, lower panel; Fig. S1, ESI $\dagger) .{ }^{29-31}$ These effects were also observed by AFM tapping mode imaging where the protein particle radii, heights, and surface roughness $\left(R_{\mathrm{q}}\right)$ values increase by a factor of 2 , 1.5 , and 2 , respectively, in the presence of $\mathrm{Ca}(\mathrm{II})$ and by a factor of 5,7 , and 6 , respectively, in the presence of $5: 1 \mathrm{Mg}$ (II): $\mathrm{Ca}$ (II) relative to low ionic strength conditions (Fig. S2, ESI $\dagger$ ). This sensitivity to ionic conditions at constant pH (Fig. 1) indicates that AP7 forms ion-responsive porous hydrogel particles.

What effect do these ion-responsive hydrogel particles have on the calcium carbonate nucleation process under seawater conditions? Under protein-deficient conditions calcite, aragonite, and $\mathrm{MgC}$ mineral phases form over a $60 \mathrm{~min}$ period (Fig. 2 top panel; Fig. S3-S7, Table S1, ESI $\dagger$ ). When we conducted these same assays with AP7, we expected to see phenomena similar to what was reported in calcite-based assays: the formation of protein aggregates that deposited onto existing crystals and facilitated the growth of highly modified crystals over a 60 min period..$^{25-28}$ However, using the same AP7 concentrations as per past studies, we found something quite different: we observed a low incidence of bulk solution $\mathrm{MgC}$ and aragonite crystal growth but a high frequency of mesoscale protein hydrogel deposition (Fig. 2, lower panel; 

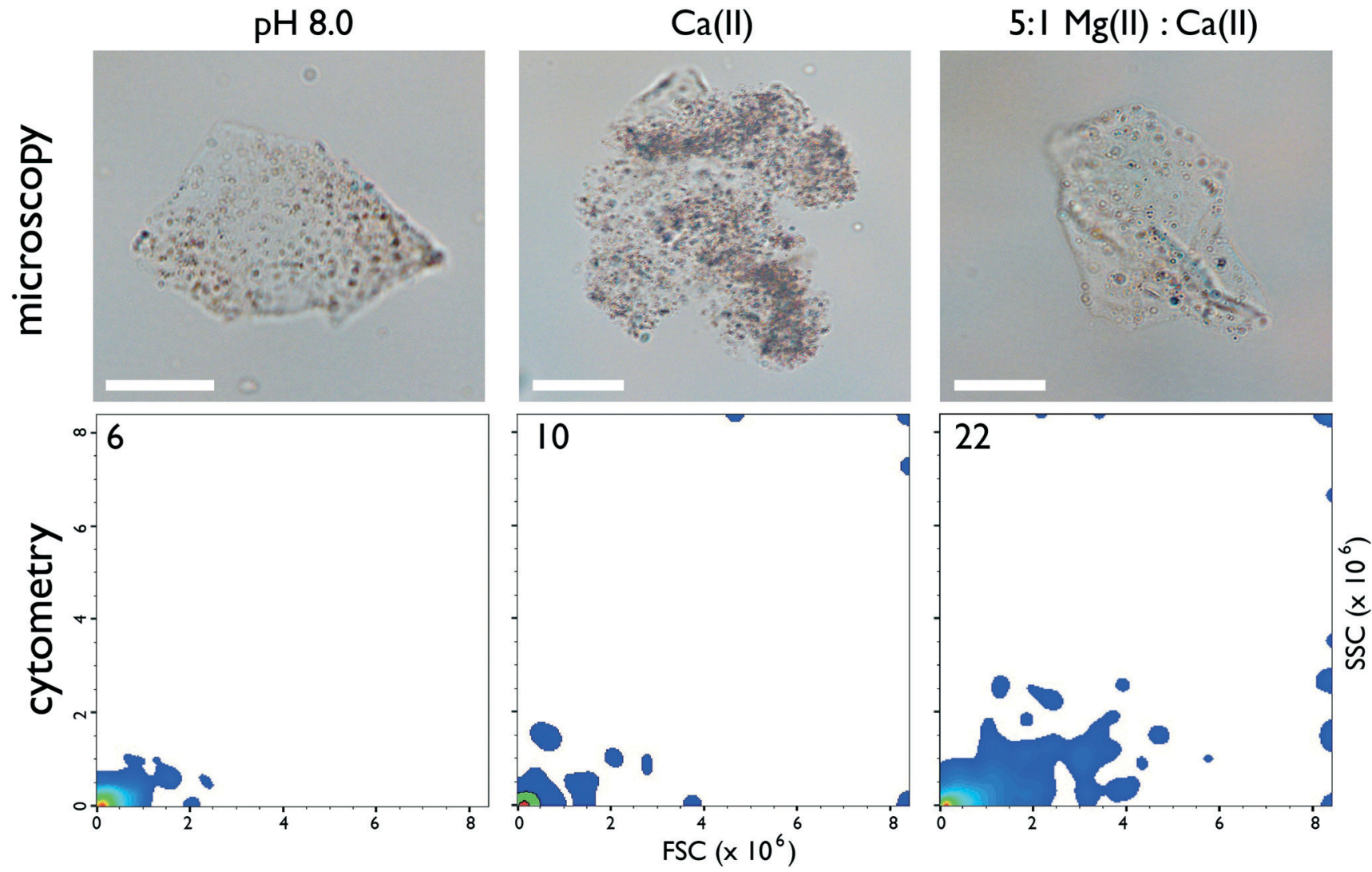

Fig. 1 (Top panel) Representative brightfield light microscopy imaging (60x) of AP7 hydrogel particles $(50 \mu M$ sample). Scalebars $=25 \mu m$. (Bottom panel) Flow cytometry 2-D density plots of particle size (forward scattered light or FSC) as a function of particle granularity (sidescattered light or SSC) for $50 \mu \mathrm{M}$ AP7. The number in the left-hand corner refers to the number of hydrogel populations resolved by particle size and granularity on each plot. Legend to plot: $\mathrm{pH} 8.0=10 \mathrm{mM} \mathrm{HEPES} ; \mathrm{Ca}(॥)=10 \mathrm{mM} \mathrm{HEPES}, 10 \mathrm{mM} \mathrm{CaCl} 2 ; 5: 1 \mathrm{Mg}(॥): \mathrm{Ca}(॥)=10 \mathrm{mM}$ HEPES, $10 \mathrm{mM} \mathrm{CaCl}_{2}, 50 \mathrm{mM} \mathrm{MgCl}$. Annotated 2D plots showing particle populations and $1 \mathrm{D}$ particle count histogram distributions can be found in ESI, $\uparrow$ Fig. S1.

Fig. S3, ESI†). A closer examination of these hydrogels revealed the presence of small, round, nanoparticle cluster networks within the gels (Fig. S3 and S4, ESI $\dagger$ ) and these particles were confirmed to contain both $\mathrm{Mg}$ (II) and $\mathrm{Ca}$ (II) (Fig. S6, ESI $\dagger$ ). MicroRaman analysis indicated that an aragonite phase is a component of these hydrogels (Fig. S7, ESI $\dagger$ ). Hence, relative to the control scenario, aragonite, $\mathrm{MgC}$, and calcite mineral formation appears to be taking place preferentially within the AP7 protein hydrogel particles as opposed to bulk solution.

From the foregoing we suspected that in a seawater environment AP7 hydrogel particles are a significant species in terms of number and size and may be attracting ion clusters, thus competing with free bulk nucleation processes. To verify this we turned to quantitative $\mathrm{Ca}$ (II)-selective electrode potentiometric measurements ${ }^{13-17}$ where either $\mathrm{CaCl}_{2}$ or $5: 1$ $\mathrm{MgCl}_{2}: \mathrm{CaCl}_{2}$ are continually dosed into carbonate buffer and PNC and ACC formation in bulk solution is monitored at $\mathrm{pH}$ 8.5. Note that, compared to our mixing experiments (Fig. 2), these potentiometric titrations are $\mathrm{pH}$ regulated and involve slower dosing of $\mathrm{Ca}$ (II) and $\mathrm{Mg}$ (II) into carbonate solutions and thus provide a different kinetic scenario for nucleation. As shown in Fig. 3 and described in ESI, in Mg(II)-free condi- tions AP7 hydrogel particles prolong the time interval for PNC formation (Fig. 3A) but neither stabilize nor destabilize PNC clusters (i.e., linear region slopes are identical) ${ }^{13-17}$ and there is no detectable impact of AP7 hydrogel particles on ACC formation and stabilization processes (Fig. 3C, note sigmoidal region endpoints are the same). However, within a seawater environment, a different scenario is at work. Here, the initial ion association and PNC stability in bulk solution are unaffected by both $\mathrm{Mg}$ (II) ions and AP7 (Fig. 3B). However, the time interval for PNC formation and the corresponding nucleation of ACC are delayed by a factor of 2 or 6 when $\mathrm{Mg}$ (II) or $\mathrm{Mg}$ (II)/500 nM AP7 are present, respectively, and at 1 $\mu \mathrm{M}$ AP7, we are unable to detect ACC nucleation events in bulk solution (Fig. 3B, Table S2, ESI $\dagger$ ) as evidenced by the absence of a peak region and subsequent sigmoidal region. This indicates that $\mathrm{Ca}$ (II) ions are being incorporated into ionic clusters but these clusters are not forming ACC in bulk solution. Thus, we conclude the following: since mineral nanoparticles form within AP7 hydrogel particles during this same time period (Fig. 2), and we know that AP7 can assemble mineral nanoparticles in solution, ${ }^{27}$ then the nucleation of ACC in bulk solution is severely restricted as a result of the recruitment or capture of ion clusters or PNCs by the AP7 


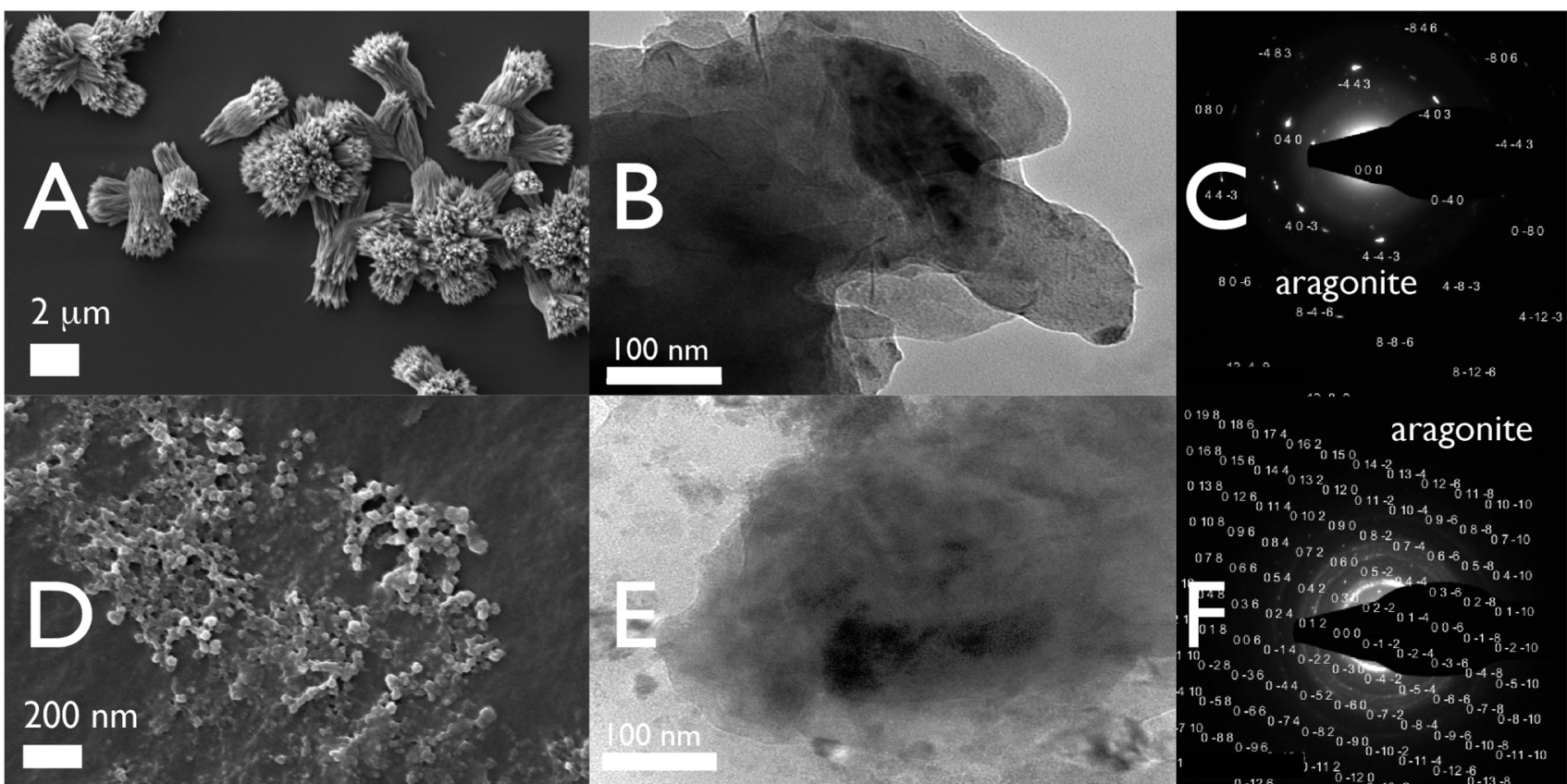

Fig. $260 \mathrm{~min} \mathrm{Mg}(\Perp)$ : $\mathrm{Ca}($ (I) 5:1 micromineralization assays. (A) SEM images of Si wafer captured deposits taken from (-) AP7 protein deficient assays; (B and C) TEM images and selected area diffraction (SAD) patterns of dried $10 \mu \mathrm{L}$ supernatant samples taken from (-) AP7 protein deficient assays. (D) SEM images of Si wafer captured deposits taken from assays containing $50 \mu \mathrm{M}$ AP7. (E and F) TEM images and selected area diffraction (SAD) patterns of dried $10 \mu \mathrm{L}$ supernatant samples taken from assays containing $50 \mu \mathrm{M}$ AP7. In (+) AP7 assays, note extensive protein aggregation and the presence of nanoparticle clusters within the protein aggregates. Results obtained from 15, 30, and 60 min assays and CrysTBox indexed and annotated SAD patterns can be found in ESI, $\uparrow$ Fig. S3 and S4.
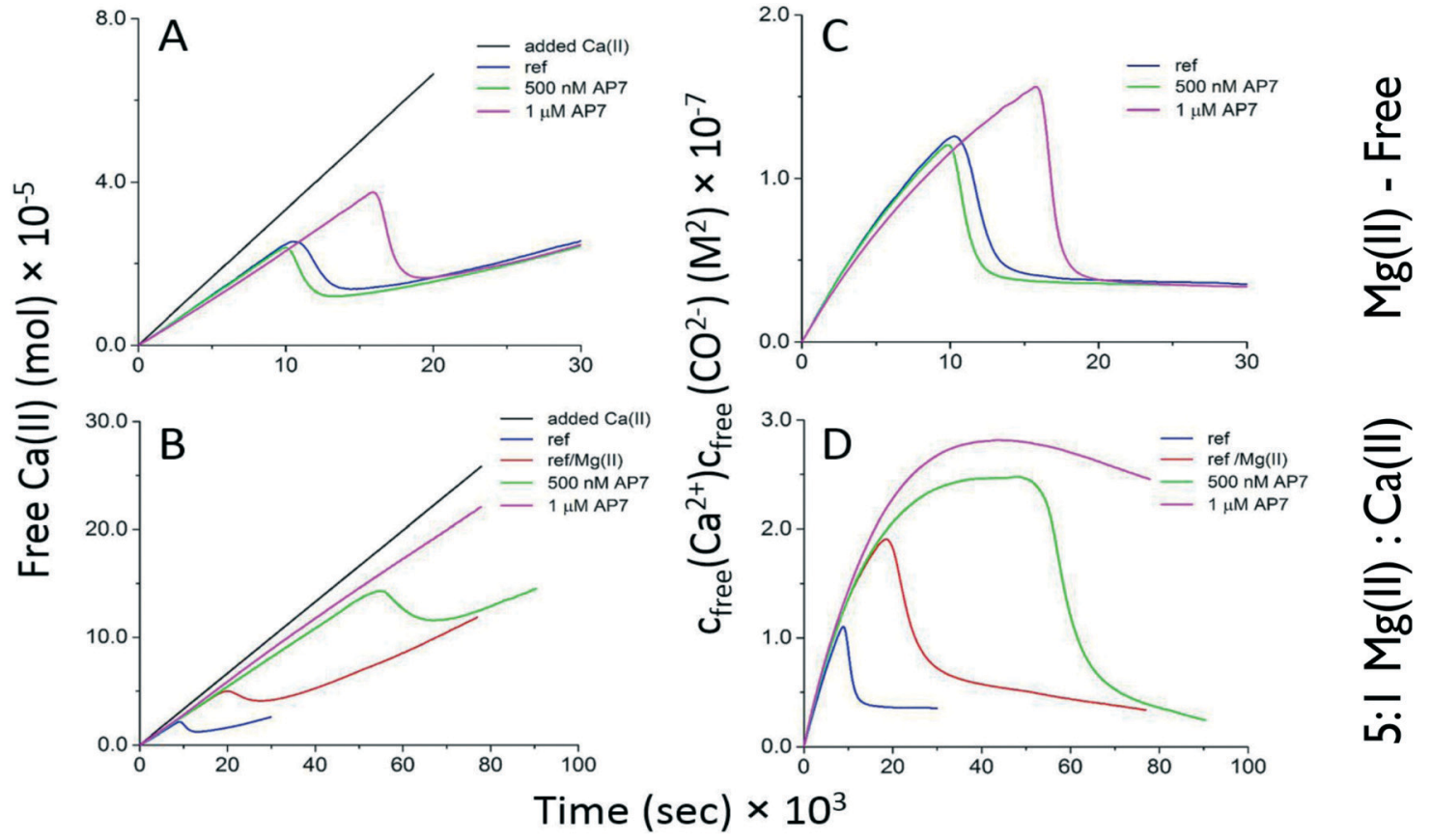

Fig. 3 Time-dependent development of free $\mathrm{Ca}(\Perp)$ ion concentration $[\mathrm{A}=$ no $\mathrm{Mg}(\mathrm{I})$ ions; $\mathrm{B}=\mathrm{Mg}(॥): \mathrm{Ca}(॥)=5: 1]$ and $\mathrm{calcium}$ carbonate ion product $[C=$ no $M g(॥)$ ions; $D=M g(I): C a(॥)=5: 1]$ in potentiometric titrations of $500 \mathrm{nM}$ and $1 \mu \mathrm{M}$ AP7 in $10 \mathrm{mM}$ carbonate buffer, pH 8.5 . Experiments were performed in duplicate (not shown), and the reproducibility was good (see Table $\mathrm{S} 2 \dagger$ ). Ref $=$ protein-deficient reference without $\mathrm{Mg}(I)$ ions present; Ref/Mg(II) = protein-deficient reference in the presence of $\mathrm{Mg}(I)$ ions.

hydrogel particles (Fig. 1-3). With regard to ACC formation and stability, we note in Fig. 3B that the endpoints of the sig- moidal curves are similar for protein-deficient and $500 \mathrm{nM}$ AP7 samples, which indicates that AP7 and Mg(II) ions do not 
affect ACC formation (note: at $1 \mu \mathrm{M}$ AP7 ACC nucleation is not occurring at this protein concentration, at least in the bulk solution). ${ }^{13-17}$ With regard to post-nucleation solubilities or ACC stability (Fig. 3D), we note that the curves are very similar for the protein-deficient and $500 \mathrm{nM}$ AP7 samples, with a small decrease noted in the solubility terms for both conditions (Table S1, ESI $\dagger$ ). Collectively, these current results are consistent with the behavior of AP7 at $\mathrm{pH} 9.0$ in the absence of $\mathrm{Mg}$ (II) ions: ${ }^{26,27} \mathrm{AP7}$ hydrogel particles do not significantly impact either ACC formation or ACC stabilization in bulk solution. This provides an important piece of information relative to protein-mediated polymorph formation: no new AP7 protein functionalities emerge in the presence of $\mathrm{Mg}(\mathrm{II})$.

\section{Conclusions}

Our present study now adds three new observations regarding the molecular behavior of an intrinsically disordered, amyloid-like aggregation-prone abalone shell nacre protein, AP7, within a seawater environment. First, under a variety of conditions AP7 forms mesoscale porous hydrogel particles but within in a $5: 1 \mathrm{Mg}$ (II): $\mathrm{Ca}$ (II) environment these particles possess the widest range of dimensions and internal or structural complexities (Fig. 1). At this time we do not know what internal alterations are occurring within the protein hydrogels that would affect side-scattered light parameters, although we postulate that these phenomena may be related to alterations in internal porosities or morphologies (Fig. 1) and this possibility will be examined in subsequent studies. Second it is not known if the increase in AP7 aggregation is due to either an increase in ionic strength (i.e., $50 \mathrm{mM} \mathrm{MgCl}_{2} / 10$ $\mathrm{mM} \mathrm{CaCl} \mathrm{C}_{2}$ versus $10 \mathrm{mM} \mathrm{CaCl}$ ) or if it is $\mathrm{Mg}$ (II) ion-specific. We believe that the latter is plausible, since $\mathrm{Mg}$ (II) was detected in assay-generated AP7 hydrogel particles (Fig. S6, ESI $\dagger$ ) and it is known that AP7 can interact with different multivalent ions. ${ }^{28}$ Thus, it would be worthwhile to study $\mathrm{Mg}$ (II) - AP7 binding in more detail and determine if specific or non-specific protein - metal ion interactions drive the protein aggregation process to higher levels.

Second, under seawater conditions AP7 hydrogel particles significantly impact the in vitro mineralization process to a degree not seen in earlier Mg(II)-free AP7 studies (Fig. 2 and 3). ${ }^{25-27}$ Specifically, we note that initial ion association in bulk solution is not affected by the presence of AP7 and $\mathrm{Mg}$ (II) ions (Fig. 3B) as evidenced by the similarities in the initial potentiometric slopes. However, all subsequent observations (Fig. 2; Fig. S3, S4, S6 and S7, ESI $\dagger$ ) clearly show that protein hydrogel particles contain calcium carbonate species - including aragonite - yet bulk solution ACC nucleation is inhibited (Fig. 3). Given that AP7 can assemble mineral nanoparticles, ${ }^{27}$ if we take all these observations into consideration our results indicate that the AP7 protein hydrogel particles "hijack" the mineralization process by acquiring calcium carbonate precursors from bulk solution and incorporating these within a thermodynamic protein hydrogel environment where aragonite and $\mathrm{MgC}$ formation crystal growth can occur. Hypothetically, if we extrapolate this process to the nacre layer, then AP7 in concert with other nacre proteins could form hydrogels that dictate where and when nucleation can occur within the nacre and thus impact downstream events such as protein-mediated polymorph stabilization, nanoparticle organization, and the assembly of nanoparticles into mesoscale nacre aragonite tablets. ${ }^{32-34}$ Further experimentation will be required to establish if this does indeed occur in situ. Third, it is important to note that $\mathrm{Mg}$ (II) does not induce any new mineralization functionalities for AP7, such as the ability to create hydrogel particles (Fig. 1), stabilize ACC, alter PNC stabilities (Fig. 3), or promote additional aragonite or $\mathrm{MgC}$ formation (Fig. 2). Rather, $\mathrm{Mg}$ (II) ions enhance inherent AP7 aggregation and mineralization activity. Furthermore, $\mathrm{Mg}$ (II) and AP7 cooperatively induce synergistic effects on the mineralization process (Fig. 3). At this time we do not know if the Mg(II) ion enhancement of AP7 aggregation and mineralization function are unique to AP7 alone, or, represent a general trend across other nacre-associated proteomes. However, we note that similar $\mathrm{Mg}$ (II) ion effects were reported for biomimetic polymers $^{35}$ and thus this might be the case for some nacre proteins as well.

\section{Acknowledgements}

This research was supported by the U.S. Department of Energy, Office of Basic Energy Sciences, Division of Materials Sciences and Engineering under Award DE-FG02-03ER46099 (JSE). YCH is supported by a doctoral fellowship of the Taiwanese Ministry of Education. DG is a Research Fellow of the Zukunftskolleg of the University of Konstanz. This report represents contribution number 84 from the Laboratory for Chemical Physics, New York University.

\section{Notes and references}

1 C. Pan, D. Fang, G. Xu, J. Liang, G. Zhang, H. Wang, L. Xie and R. Zhang, J. Biolumin. Chemilumin., 2014, 289, 2776.

2 Z. Yan, G. Jing, N. Gong, C. Li, Y. Zhou, X. Xiew, L. Xie and R. Zhang, Biomacromolecules, 2007, 8, 3597.

3 J. B. Thompson, G. T. Paloczi, J. H. Kindt, M. Michenfelder, B. L. Smith, G. Stucky, D. E. Morse and P. K. Hansma, Biophys. J., 2000, 79, 3307.

4 F. Heinemann, L. Treccani and M. Fritz, Biochem. Biophys. Res. Commun., 2006, 344, 45.

5 I. M. Weiss, N. Tuross, L. Addadi and S. Weiner, J. Exp. Zool., 2002, 293, 478.

6 R. A. Metzler, J. S. Evans, C. E. Kilian, D. Zhou, T. H. Churchill, P. N. Appathurai, S. N. Coppersmith and P. U. P. A. Gilbert, J. Am. Chem. Soc., 2010, 132, 6329.

7 W. Sun, S. Jayaraman, W. Chen, K. A. Persson and G. Ceder, Proc. Natl. Acad. Sci. U. S. A., 2015, 112, 3199.

8 V. De Choudens-Sánchez and L. A. González, J. Sediment. Res., 2009, 79, 363-376. 
9 R. M. Coggon, D. A. Teagle, C. E. Smith-Duque, J. C. Alt and M. J. Cooper, Science, 2010, 327, 1114-1117.

10 R. A. Berner, Geochim. Cosmochim. Acta, 1975, 39, 489.

11 J. J. De Yoreo, P. U. P. A. Gilbert, N. A. J. M. Sommerdijk, R. L. Penn, S. Whitelam, D. Joester, H. Zhang, J. D. Rimer, A. Navrotsky, J. F. Banfield, A. F. Wallace, F. M. Michel, F. C. Meldrum, H. Cölfen and P. M. Dove, Science, 2015, 349, 498.

12 A. F. Wallace, L. O. Hedges, A. Fernandez-Martinez, P. Raiteri, J. D. Gale, G. A. Waychunas, S. Whitelam, J. F. Banfield and J. J. De Yoreo, Science, 2013, 341, 885.

13 D. Gebauer, M. Kellermeier, J. D. Gale, L. Bergstrom and H. Cölfen, Chem. Soc. Rev., 2014, 43, 2348-2371.

14 R. Demichelis, P. Raiteri, J. D. Gale, D. Quigley and D. Gebauer, Nat. Commun., 2011, 2, 1.

15 D. Gebauer, H. Cölfen, A. Verch and M. Antonietti, Adv. Mater., 2009, 21, 435.

16 M. Kellermeier, H. Cölfen and D. Gebauer, in Research Methods in Biomineralization Science, Book Series: Methods in Enzymology, ed. J. J. De Yoreo, 2013, vol. 532, p. 45.

17 A. Verch, M. Antonietti and H. Cölfen, Z. Kristallogr. - Cryst. Mater., 2012, 227, 718.

18 M. Farhadi-Khouzani, D. M. Chevrier, P. Zhang, N. Hedin and D. Gebauer, Angew. Chem., Int. Ed., 2016, 55, 8117.

19 A. Fernandez-Martinez, B. Kalkan, S. M. Clark and G. A. Waychunas, Angew. Chem., Int. Ed., 2013, 52, 8354.

20 J. D. Rodriguez-Blanco, S. Shaw and L. G. Benning, Nanoscale, 2011, 3, 265.
21 J. Ihli, W. C. Wong, E. H. Noel, Y. Y. Kim, A. N. Kulak, H. K. Christenson, M. J. Duer and F. C. Meldrum, Nat. Commun., 2014, 5, 3169.

22 D. J. Jackson, C. McDougall, B. Woodcroft, P. Moase, R. A. Rose, M. Kube, R. Reinhart, D. S. Rokhsar, C. Montagnani, C. Joube, D. Piquemal and B. M. Degnan, Mol. Biol. Evol., 2010, 27, 591.

23 G. Zhang, et al., Nature, 2012, 490, 49.

24 D. Fang, G. Xu, Y. Hu, C. Pan, L. Xie and R. Zhang, PLoS One, 2011, 6, 1-13.

25 E. P. Chang, G. Williamson and J. S. Evans, Cryst. Growth Des., 2015, 15, 1577-1582.

26 I. Perovic, E. P. Chang, A. Verch, A. Rao, H. Cölfen, R. Kröger and J. S. Evans, Biochemistry, 2014, 53, 7259.

27 E. P. Chang, J. A. Russ, A. Verch, R. Kröger, L. A. Estroff and J. S. Evans, Biochemistry, 2014, 53, 4317.

28 F. F. Amos, M. Ndao, C. B. Ponce and J. S. Evans, Biochemistry, 2011, 50, 8880.

29 J. Cui, M. Bjornmalm, K. Liang, C. Xu, J. P. Best, X. Zhang and F. Caruso, Adv. Mater., 2014, 26, 7295.

30 S. H. Cho, J. M. Godin, C. H. Chen, W. Qiao, H. Lee and Y. H. Lo, Biomicrofluidics, 2010, 4, 043001.

31 G. Henel and J. L. Schmitz, Lab. Med., 2007, 38, 428.

32 G. Zhang and X. Li, Cryst. Growth Des., 2012, 12, 4306.

33 X. Li and Z. Huang, Phys. Rev. Lett., 2009, 102, 075502.

34 G. Zheng and J. Xu, J. Struct. Biol., 2013, 182, 36-43.

35 S. L. P. Wolf, K. Jähme and D. Gebauer, CrystEngComm, $2015,17,6857-6862$. 